\title{
Genetic predisposition, dietary restraint and disinhibition in relation to short and long-term weight loss
}

Citation for published version (APA):

Verhoef, S. P., Camps, S. G., Bouwman, F. G., Mariman, E. C., \& Westerterp, K. R. (2014). Genetic predisposition, dietary restraint and disinhibition in relation to short and long-term weight loss. Physiology \& Behavior, 128, 247-251. https://doi.org/10.1016/j.physbeh.2014.02.004

Document status and date:

Published: 10/04/2014

DOI:

10.1016/j.physbeh.2014.02.004

Document Version:

Publisher's PDF, also known as Version of record

\section{Document license:}

Taverne

Please check the document version of this publication:

- A submitted manuscript is the version of the article upon submission and before peer-review. There can be important differences between the submitted version and the official published version of record.

People interested in the research are advised to contact the author for the final version of the publication, or visit the DOI to the publisher's website.

- The final author version and the galley proof are versions of the publication after peer review.

- The final published version features the final layout of the paper including the volume, issue and page numbers.

Link to publication

\footnotetext{
General rights rights.

- You may freely distribute the URL identifying the publication in the public portal. please follow below link for the End User Agreement:

www.umlib.nl/taverne-license

Take down policy

If you believe that this document breaches copyright please contact us at:

repository@maastrichtuniversity.nl

providing details and we will investigate your claim.
}

Copyright and moral rights for the publications made accessible in the public portal are retained by the authors and/or other copyright owners and it is a condition of accessing publications that users recognise and abide by the legal requirements associated with these

- Users may download and print one copy of any publication from the public portal for the purpose of private study or research.

- You may not further distribute the material or use it for any profit-making activity or commercial gain

If the publication is distributed under the terms of Article $25 \mathrm{fa}$ of the Dutch Copyright Act, indicated by the "Taverne" license above, 


\title{
Genetic predisposition, dietary restraint and disinhibition in relation to short and long-term weight loss
}

\author{
Sanne P.M. Verhoef* , Stefan G.J.A. Camps, Freek G. Bouwman, Edwin C.M. Mariman, Klaas R. Westerterp \\ Maastricht University, Department of Human Biology, Nutrition and Toxicology Research Institute Maastricht, 6200 MD, Maastricht, The Netherlands
}

\section{H I G H L I G H T S}

- A high predisposition score is associated with high body weight

- A high predisposition score is associated with more weight loss

- Long-term weight loss is mainly associated with changes in eating behaviour

\section{A R T I C L E I N F O}

\section{Article history:}

Received 17 October 2012

Received in revised form 22 September 2013

Accepted 4 February 2014

Available online 14 February 2014

\section{Keywords:}

Single nucleotide polymorphism

Weight loss

Dietary restraint

Disinhibition

\begin{abstract}
A B S T R A C T
Background: Interindividual differences in response to weight loss and maintenance thereafter are ascribed to genetic predisposition and behavioral changes.

Objective: To examine whether body weight and short and long-term body weight loss were affected by candidate single nucleotide polymorphisms (SNPs) and changes in eating behavior or by an interaction between these genetic and behavioral factors.

Methods: 150 healthy subjects (39 males, 111 females) aged $20-50 \mathrm{y}$ with a BMI of $27-38 \mathrm{~kg} / \mathrm{m}^{2}$ followed a very low energy diet for 8 -weeks, followed by a 3-month weight maintenance period. SNPs were selected from six candidate genes: ADRB2, FTO, MC4R, PPARG, PPARD, and PPARGC1A. Changes in eating behavior were determined with the Three Factor Eating Questionnaire.

Results: A high genetic predisposition score was associated with a high body weight at baseline and more shortterm weight loss. From the six selected obesity-related SNPs, FTO was associated with increased body weight at baseline, and the effect allele of PPARGC1A was positively associated with short-term weight loss, when assessed for each SNP separately. Long-term weight loss was associated with a larger increase in dietary restraint and larger decrease in disinhibition.

Conclusion: During long-term weight loss, genetic effects are dominated by changes in eating behavior.
\end{abstract}

(C) 2014 Elsevier Inc. All rights reserved.

\section{Introduction}

Obesity results from a chronic imbalance between energy intake and expenditure [1]. The increasing prevalence of obesity coincides with changes in dietary habits due to high availability of energy-dense foods, suggesting a causal link [2]. However, some individuals seem resistant to becoming overweight or obese. Inter-individual variation in the susceptibility to develop obesity can be partly explained by genetics. Family and twin studies have shown that the genetic contribution can be $40-70 \%$ [3,4]. Genome-wide association studies (GWAS), already identified 52 genetic loci to be unequivocally associated with obesity related-traits [5]. However, the effects of the loci

\footnotetext{
* Corresponding author. Tel.: + 3143 3881617; fax: + 31433670976

E-mail address: s.verhoef@maastrichtuniversity.nl (S.P.M. Verhoef).
}

on obesity-susceptibility are small and explain only a small fraction of the total variation with a poor predictive ability [5-7]. Studying the GWAS-identified loci in longitudinal cohort studies can contribute to elucidating new physiological pathways that underlie obesitysusceptibility.

Most association studies focus on single nucleotide polymorphisms (SNPs) in relation to body weight, instead of changes in body weight. Successfully maintaining weight loss, defined as "keeping off an intentional loss of at least $10 \%$ body weight for at least one year" is only achieved in around $20 \%$ of the cases [8,9]. Individual differences in weight loss and regain may in part be caused by a genetic predisposition to resist weight loss or promoting weight gain [10]. Twin studies on the response to long-term negative energy balance have demonstrated a much larger variability between pairs than within pairs $[11,12]$, suggesting that there is also a genetic contribution in the resistance for body weight loss and maintenance. 
In this study, we tested the combined and individual effect of six genetic variants, which had shown associations with obesity-related traits: rs9939609 of fat mass and obesity associated (FTO) gene; rs17782313 of melanocortin 4 receptor (MC4R) gene; rs1042713 of B2-adrenergic receptor (ADRB2) gene; rs1801282 of peroxisome proliferator-activated receptor $\gamma 2$ (PPAR $\gamma 2$ ) gene; rs8192678 of peroxisome proliferator-activated receptor $\gamma$ coactivator-1 $\alpha$ (PPARGC1 $\alpha)$ gene; and rs2076168 of peroxisome proliferator-activated receptor $\delta$ (PPAR $\delta$ ) gene. The aim of the study was to examine whether body weight changes during an 8-week weight loss period and subsequent follow-up of 3-months were affected by the six selected SNPs and by changes in eating behavior, or by an interaction between these genetic and behavioral factors.

\section{Material and methods}

\subsection{Subjects}

150 healthy subjects ( 39 males, 111 females) aged $20-50$ y with a BMI of $27-38 \mathrm{~kg} / \mathrm{m}^{2}$ participated in the study, which started in February 2010. The weight loss diet consisted of 8 weeks of very low energy diet providing 2.1 MJ/day (Modifast; Nutrition et Santé Benelux, Breda, The Netherlands). This diet was a protein-enriched formula diet that provided $50 \mathrm{~g}$ carbohydrates, $52 \mathrm{~g}$ protein, $7 \mathrm{~g}$ fat and a micronutrient content, which meets the Dutch recommended daily allowance. Vegetables were allowed in addition to the diet. The weight loss period was followed by a weight maintenance period of 3 months, in which subjects were instructed to maintain their newly achieved body weight. Measurements were done at rest and following an overnight fast at three time points; before weight loss, after weight loss and after 3 months follow-up. The study was conducted according to the guidelines laid down in the Declaration of Helsinki and all procedures involving human subjects were approved by the Central Committee on Human Research and by the Medical Ethical Committee of Maastricht University. Written informed consent was obtained from all subjects. The study was registered in ClinicalTrials.gov (registration number: NCT01015508).

\subsection{Anthropometry}

Height was measured at screening to the nearest $0.1 \mathrm{~cm}$ with the use of a wall-mounted stadiometer (model 220; Seca, Hamburg, Germany). Body weight was measured with subjects in underwear after an overnight fast using a calibrated scale of the BodPod ${ }^{\circledR}$. Body mass index (BMI) was calculated by dividing body weight by height squared $\left(\mathrm{kg} / \mathrm{m}^{2}\right)$.

Body composition was calculated from body volume (BodPod ${ }^{\circledR}$, Life measurement, Concord, CA, USA) [13] and total body water (TBW) [14] as assessed with the deuterium dilution technique, using Siri's threecompartment model [15]. The dilution of the deuterium isotope $\left({ }^{2} \mathrm{H}_{2} \mathrm{O}\right)$ is a measure for total body water. Subjects wore tightly fitting bathing suits and a swim cap during the volume-measurements in the $\operatorname{BodPod} \circledast$, and had not engaged in exercise at least $1 \mathrm{~h}$ prior to the test.

\subsection{Questionnaires}

To determine whether attitude toward food intake changed during weight loss and maintenance, a validated Dutch translation of the three-factor eating questionnaire (TFEQ) was used [16]. Changes in dietary restraint and disinhibition scores were used as indicators for changes in eating behavior and different disinhibition and restraint outcomes have been associated with distinct weight and behavior outcomes [17].

\subsection{DNA isolation and genotyping}

Blood was collected in an EDTA tube during screening and the buffy coat was stored at $-80^{\circ} \mathrm{C}$. Genomic DNA was isolated from the buffy
Table 1

Subject characteristics (mean $\pm \mathrm{SD}$ ) on baseline (t0), after weight loss (t2) and after 3month (t5).

\begin{tabular}{lcccc}
\hline & t0 & t2 & t5 & P-value $^{\mathrm{a}}$ \\
\hline Body weight $(\mathrm{kg})$ & $92.6 \pm 12.3$ & $83.2 \pm 10.9^{\mathrm{b}}$ & $84.7 \pm 11.7^{\mathrm{b}}$ & $<0.001$ \\
BMI $\left(\mathrm{kg} / \mathrm{m}^{2}\right)$ & $32.0 \pm 3.1$ & $28.7 \pm 3.0^{\mathrm{b}}$ & $29.2 \pm 3.2^{\mathrm{b}}$ & $<0.001$ \\
Fat mass $(\mathrm{kg})$ & $38.6 \pm 7.8$ & $31.2 \pm 7.8^{\mathrm{b}}$ & $30.9 \pm 8.6^{\mathrm{b}}$ & $<0.001$ \\
Percentage fat mass $(\%)$ & $41.6 \pm 6.6$ & $37.4 \pm 7.4^{\mathrm{b}}$ & $33.5 \pm 8.5^{\mathrm{b}}$ & $<0.001$ \\
Dietary restraint & $7.5 \pm 3.8$ & $12.4 \pm 4.2^{\mathrm{b}}$ & $12.0 \pm 4.2^{\mathrm{b}}$ & $<0.001$ \\
Disinhibition & $6.5 \pm 2.7$ & $4.9 \pm 2.6^{\mathrm{b}}$ & $5.3 \pm 2.8^{\mathrm{b}}$ & $<0.001$ \\
Hunger & $5.1 \pm 3.0$ & $3.7 \pm 3.0^{\mathrm{b}}$ & $3.4 \pm 2.9^{\mathrm{b}}$ & $<0.001$ \\
\hline
\end{tabular}

BMI: body mass index.

a Difference over time (repeated measures ANOVA).

b Significantly different from baseline, $\mathrm{P}<0.01$.

coat using the QIAamp mini blood kit (Qiagen, Amsterdam, The Netherlands). Six SNPs were selected based on GWAS and intervention studies, which associated them with obesity (Table 1). Genotypes were coded 0,1 or 2 according to the number of risk alleles for each SNP. From these codes a genetic predisposition score (GPS) was constructed for each individual by summing the risk alleles across the six SNPs, as previously done by other authors $[5,18,19]$.

Genotyping of five SNPs was performed using commercially available TaqMan SNP genotyping assays from Applied Biosystems (Foster City, California, USA). The procedure was performed according to the manufacturer's protocol and measured on an Applied Biosystems 7900 HT Fast Real-Time PCR system. Allelic calls were determined semiautomatically using the allelic discrimination software of Applied Biosystems. The Pro12Ala polymorphism of the PPAR 2 gene was characterized using the polymerase chain reaction-restriction fragment length polymorphism (PCR-RFLP) assay. The primers used were 5'-GCCAATTC AAGCCCAGTC- $3^{\prime}$ and 5'-GATATGTTTGCAGACAGTGTATCAGTGAAGGAAT CGCTTTCCG- $3^{\prime}$. The cycling conditions were $95^{\circ} \mathrm{C}$ for $5 \mathrm{~min}, 30$ cycles of $95{ }^{\circ} \mathrm{C} / 30 \mathrm{~s}, 56{ }^{\circ} \mathrm{C} / 45 \mathrm{~s}, 68{ }^{\circ} \mathrm{C} / 45 \mathrm{~s}$ and followed by $68{ }^{\circ} \mathrm{C}$ for $7 \mathrm{~min}$. The restriction enzyme BstU-I was used, which generated the following fragments: 270 bp (Pro12Pro); 270, 227, 43 bp (Pro12Ala) and 227, 43 bp (Ala12Ala).

\subsection{Statistical analysis}

Data are presented as mean and their standard deviations, unless otherwise indicated. A Chi-square test was used to check whether the allele frequencies were in Hardy Weinberg equilibrium. ANOVA repeated measures was carried out to determine changes over time. Mean baseline values and changes in weight during weight loss and follow-up periods were compared between groups with ANOVA. Corrections for multiple testing were performed by using Bonferroni correction. Each SNP was tested individually, with age, sex and baseline value for that particular dependent variable as covariates. Linear regressions were used to test for associations. Significance was defined as $\mathrm{P}<0.05$. All of the statistical analyses were executed with SPSS version 16.0 for Macintosh OS X (SPSS Inc., Chicago, IL).

\section{Results}

Body weight, BMI, fat mass, percentage fat mass, and waist and hip circumference decreased significantly during weight loss and remained significantly lower after 3-month follow-up compared to baseline (Table 1). Dietary restraint increased and disinhibition and hunger decreased significantly during weight loss and remained significantly below baseline values during follow-up.

\subsection{Genetic predisposition}

All SNPs were in Hardy Weinberg equilibrium (Table 2). To determine the genetic contribution of the selected SNPs, differences in body weight at baseline and body weight changes during short and long-term weight 
Table 2

Genotypic and allelic distributions per single nucleotide polymorphism.

\begin{tabular}{|c|c|c|c|c|c|c|c|}
\hline Gene & SNP & G & $\mathrm{F}(\mathrm{N})$ & $\mathrm{F}(\%)$ & Allele $^{a}$ & $\mathrm{~F}(\%)$ & HWE \\
\hline \multirow[t]{3}{*}{ FTO } & rs9936909 & AA & 25 & 16.9 & A & 38.9 & 0.65 \\
\hline & & AT & 65 & 43.9 & $\mathrm{~T}$ & 61.1 & \\
\hline & & TT & 58 & 39.2 & & & \\
\hline \multirow[t]{3}{*}{$M C 4 R$} & rs17782313 & $\mathrm{CC}$ & 15 & 10.1 & C & 24.1 & 0.19 \\
\hline & & $\mathrm{CT}$ & 46 & 31.1 & $\mathrm{~T}$ & 75.9 & \\
\hline & & TT & 87 & 58.8 & & & \\
\hline \multirow[t]{3}{*}{ ADRB2 } & rs1042713 & GG & 56 & 37.8 & G & 62.3 & 0.92 \\
\hline & & GA & 71 & 48.0 & A & 37.7 & \\
\hline & & AA & 21 & 14.2 & & & \\
\hline \multirow[t]{3}{*}{ PPARD } & rs2076168 & GG & 16 & 10.9 & G & 28.1 & 0.33 \\
\hline & & GT & 52 & 35.4 & $\mathrm{~T}$ & 71.9 & \\
\hline & & TT & 79 & 53.7 & & & \\
\hline \multirow[t]{3}{*}{ PPARGC1A } & rs8192678 & AA & 20 & 13.6 & A & 37.2 & 0.95 \\
\hline & & AG & 70 & 47.6 & G & 62.8 & \\
\hline & & GG & 57 & 38.8 & & & \\
\hline \multirow[t]{3}{*}{ PPARG2 } & rs1801282 & Ala12Ala & 1 & 0.7 & Ala & 10.7 & 0.83 \\
\hline & (Pro12Ala) & Pro12Ala & 30 & 20.1 & Pro & 89.3 & \\
\hline & & Pro12Pro & 118 & 79.2 & & & \\
\hline
\end{tabular}

$\mathrm{G}$, genotype; $\mathrm{F}$, frequency, both absolute $(\mathrm{N})$ and relative (\%).

P-values obtained from the $\chi^{2}$-test of Hardy Weinberg equilibrium (HWE).

a Effect allele in bold.

loss were compared between the different genotypes (Table 3). Furthermore, a GPS was calculated by summing the risk alleles across the six SNPs. Multiple regression showed a positive association between GPS and body weight at baseline (Table 4), with a higher GPS associated with a higher body weight at baseline. There was no unifying effect on body weight as the GPS might have suggested when the effect of the SNPs separately was assessed (Table 3 ). There was a significant difference in body weight at baseline between FTO genotypes, with a higher body weight with the effect allele. More weight loss during energy restriction was associated with a high GPS (Table 4), thereby taking into account baseline body weight. Multiple regression with the percentage weight loss showed the same results (results not shown). Subjects with the effect allele for PPARGC1A had more short-term weight loss. During long-term weight loss there were no significant associations with GPS. Long-term weight loss was significantly different between MC4R genotypes, with less weight loss after 3-month follow-up compared to baseline in subjects with the effect allele.
Additionally, results for differences in fat mass and percentage fat mass between genotypes were comparable to those for body weight as reported above (data not shown). For dietary restraint, disinhibition and hunger scores, there were no significant differences between genotypes.

\subsection{Eating behavior}

Changes in dietary restraint were inversely correlated with changes in disinhibition during both short and long-term weight loss (respectively $\mathrm{R}^{2}=0.044 \mathrm{P}=0.011$ and $\mathrm{R}^{2}=0.082 \mathrm{P}<0.001$ ). Body weight at baseline was significantly correlated with dietary restraint and disinhibition, but did not reach significance after adjusting for age and gender (Table 5). In a multiple regression together with SNPs that showed a significant effect, body weight at baseline was associated with gender and FTO. Short-term weight loss was associated with body weight at baseline, gender and PPARGC1A. Long-term weight loss was associated with the amount of weight lost during energy restriction, gender and the change in dietary restraint and disinhibition after 3-month follow-up. No significant interaction effects between the genetic and behavioral factors were found.

\section{Discussion}

A high GPS was associated with a high body weight at baseline and more short-term weight loss. From the six selected obesity-related SNPs in this study, FTO was associated with increased body weight at baseline. The effect allele of PPARGC1A was associated with short-term weight loss when assessed for each SNP separately. Long-term weight loss was associated with a larger increase in dietary restraint and larger decrease in disinhibition.

Based on literature six SNPs were selected as being related to obesity associated-traits, and thus suggested to be candidates for associations with body weight changes. The correlations with GPS indicate that the SNPs have a negative effect on body weight, but a positive effect on short-term weight loss, with subjects with the most effect alleles losing more weight during energy restriction. However, when assessed for each SNP separately merely FTO and body weight and PPARGC1A and short-term weight loss were significantly associated. For FTO rs9936909, body weight at baseline was higher in A-allele carriers, while there were no differences in weight loss consistent with previous studies

Table 3

Baseline and changes in body weight $(\mathrm{kg})$ during short- and long-term weight loss.

\begin{tabular}{|c|c|c|c|c|c|c|c|c|}
\hline \multirow[t]{2}{*}{ Gene } & \multirow[t]{2}{*}{ Effect allele } & \multirow[t]{2}{*}{ Genotype } & \multicolumn{2}{|c|}{ Baseline weight $(\mathrm{t} 0)^{\mathrm{a}}$} & \multicolumn{2}{|c|}{$\begin{array}{l}\text { Short-term weight loss } \\
(\mathrm{t} 2-0)^{\mathrm{b}}\end{array}$} & \multicolumn{2}{|c|}{ Long-term weight loss $(\mathrm{t} 5-0)^{\mathrm{c}}$} \\
\hline & & & Mean \pm SE & P-value & Change \pm SE & P-value & Change \pm SE & P-value \\
\hline \multirow[t]{3}{*}{ FTO } & A & $\mathrm{AA}$ & $96.0 \pm 2.4$ & 0.017 & $-9.9 \pm 0.8$ & 0.333 & $-8.8 \pm 0.6$ & 0.411 \\
\hline & & AT & $93.9 \pm 1.3$ & & $-9.7 \pm 0.4$ & & $-8.0 \pm 0.4$ & \\
\hline & & TT & $90.5 \pm 1.3$ & & $-8.9 \pm 0.4$ & & $-7.8 \pm 0.4$ & \\
\hline \multirow{3}{*}{$M C 4 R$} & C & $\mathrm{CC}$ & $96.6 \pm 3.1$ & 0.353 & $-8.2 \pm 1.0$ & 0.422 & $-7.5 \pm 0.9$ & 0.049 \\
\hline & & CT & $91.3 \pm 1.6$ & & $-9.6 \pm 0.5$ & & $-7.2 \pm 0.4$ & \\
\hline & & TT & $92.6 \pm 1.2$ & & $-9.5 \pm 0.4$ & & $-8.6 \pm 0.3$ & \\
\hline \multirow{3}{*}{ ADRB2 } & G & GG & $93.5 \pm 1.6$ & 0.208 & $-9.9 \pm 0.5$ & 0.346 & $-7.3 \pm 0.4$ & 0.190 \\
\hline & & GA & $93.1 \pm 1.3$ & & $-9.0 \pm 0.4$ & & $-8.1 \pm 0.4$ & \\
\hline & & $\mathrm{AA}$ & $89.4 \pm 2.2$ & & $-8.8 \pm 0.7$ & & $-8.6 \pm 0.6$ & \\
\hline \multirow[t]{3}{*}{ PPARD } & G & GG & $91.8 \pm 2.8$ & 0.530 & $-9.9 \pm 0.9$ & 0.525 & $-8.4 \pm 0.8$ & 0.385 \\
\hline & & GT & $91.4 \pm 1.6$ & & $-9.5 \pm 0.5$ & & $-7.4 \pm 0.4$ & \\
\hline & & TT & $93.7 \pm 1.2$ & & $-9.0 \pm 0.4$ & & $-8.1 \pm 0.3$ & \\
\hline \multirow[t]{3}{*}{ PPARGC1A } & A & $\mathrm{AA}$ & $92.9 \pm 2.6$ & 0.112 & $-10.7 \pm 0.8$ & 0.023 & $-9.1 \pm 0.7$ & 0.290 \\
\hline & & $A G$ & $94.2 \pm 1.3$ & & $-9.8 \pm 0.4$ & & $-7.9 \pm 0.4$ & \\
\hline & & GG & $91.4 \pm 1.4$ & & $-8.5 \pm 0.4$ & & $-7.8 \pm 0.7$ & \\
\hline \multirow[t]{2}{*}{ PPARG2 } & Ala & Pro12Ala & $93.8 \pm 2.1$ & 0.725 & $-10.1 \pm 0.7$ & 0.189 & $-7.6 \pm 0.6$ & 0.525 \\
\hline & & Pro12Pro & $92.3 \pm 1.0$ & & $-9.2 \pm 0.3$ & & $-8.0 \pm 0.3$ & \\
\hline
\end{tabular}


Table 4

Multiple regression between body weight and body weight changes with GPS.

\begin{tabular}{llrrl}
\hline Response & Parameter & \multicolumn{1}{l}{$\mathrm{B} \pm \mathrm{SE}$} & \multicolumn{1}{l}{$\beta$} & P-value \\
\hline Baseline & GPS & $1.14 \pm 0.57$ & 0.15 & 0.049 \\
weight $(\mathrm{t} 0)$ & Gender & $-15.38 \pm 2.28$ & -0.52 & 0.000 \\
& Age & $-0.03 \pm 0.11$ & -0.02 & 0.821 \\
Short-term weight & GPS & $-0.52 \pm 0.18$ & -0.21 & 0.004 \\
loss (t2 - 0) & Gender & $2.86 \pm 0.82$ & 0.30 & 0.000 \\
& Baseline weight (t0) & $-0.11 \pm 0.03$ & -0.30 & 0.001 \\
& Age & $0.04 \pm 0.04$ & 0.07 & 0.317 \\
\hline
\end{tabular}

Response; dependent variable.

Parameter; independent variable.

$\mathrm{B}$; unstandardized regression coefficient.

$\beta$; standardized regression coefficient.

[20-22]. During short-term weight loss subjects with the A-allele of PPARGC1A rs8192678 lost more weight, but this effect was lost during long-term weight loss. There were also no differences in baseline body weight between PPARGC1A genotypes. These results were in contrast to previous studies, which showed associations with body weight and not with weight changes $[23,24]$. Long-term weight loss was significantly lower in subjects with the C-allele of MC4R rs17782313, while others have shown that this SNP was associated with body weight and not weight changes $[25,26]$. In contrast to what we expected from the literature, there were in addition to PPARGC1A and MC4R also no significant differences in body weight for the ADRB2 rs1042713 and PPARD rs2076168 $[27,28]$. Although not many studies determined the relation between SNPs and weight changes, most associations were found with PPARG2 rs1801282 [29-33], but our results could not confirm this. Many explanations for the inconsistent results in the literature have already been proposed, like low sample size, limitations of study populations and different study designs. However, a probably more important factor is the largely unknown gene-environment interactions that can mask the effect of a genetic variant, as described by Andreasen et al. [34]. Especially during a period of conscious weight loss, behavioral changes might dominate genetic effects. Furthermore, comparing studies using GPS is difficult, because a calculated GPS is not a constant variable and is different in each study depending on the different SNPs selected.

Dietary restraint and disinhibition have emerged from the literature as important indicators for eating behavior and different disinhibition and restraint outcomes have been associated with distinct weight and behavior outcomes [17]. Here, changes in dietary restraint and disinhibition were inversely correlated with each other, consistent with previous studies [35-38]. Both changes in dietary restraint and disinhibition were correlated with long-term weight loss, emphasizing the importance of both factors during periods of weight maintenance. These results confirm findings of previous studies that already have shown that the increase in dietary restraint was associated with more success in weight maintenance $[37,39,40]$. There was no effect of the SNPs on dietary restraint and disinhibition or changes in these factors, so changes in eating behavior independently predict success in long-term weight loss.

From these results we cannot exclude whether there were geneenvironment interactions masking effects of a genetic variant. In turn, dietary restraint and disinhibition do not fully cover behavioral factors, though widely used to characterize eating behavior. In addition, six SNPs as measured in 150 subjects are low compared to other genetic studies. However, this is a consequence of the design of our study, since accurate assessment of short and long-term weight loss was a limiting factor. Since these measurements are part of a larger intervention study, the selection of the SNPs comprised those previously associated with obesity-related traits in general and not specifically personality traits.

In conclusion, long-term weight loss is mainly determined by changes in eating behavior.

\section{Acknowledgments}

K.R. Westerterp and S.P.M. Verhoef designed the study. S.P.M. Verhoef, S.G.J.A. Camps and F.G. Bouwman collected the data. S.P.M. Verhoef analyzed the data and wrote the manuscript. K.R. Westerterp and E.C.M. Mariman contributed to the interpretation of the data and reviewed the manuscript. The study was executed under supervision of K.R. Westerterp. All authors read and approved the final manuscript. None of the authors had any conflict of interest.

\section{References}

[1] Tremblay A, Perusse L, Bouchard C. Energy balance and body-weight stability: impact of gene-environment interactions. Br J Nutr 2004;92(Suppl. 1):S63-6.

[2] Hill JO, Wyatt HR, Reed GW, Peters JC. Obesity and the environment: where do we go from here? Science 2003;299:853-5.

[3] Loos RJ, Bouchard C. Obesity-is it a genetic disorder? J Intern Med 2003;254:401-25.

[4] Maes HH, Neale MC, Eaves LJ. Genetic and environmental factors in relative body weight and human adiposity. Behav Genet 1997;27:325-51.

[5] Li S, Zhao JH, Luan J, Luben RN, Rodwell SA, Khaw KT, et al. Cumulative effects and predictive value of common obesity-susceptibility variants identified by genomewide association studies. Am J Clin Nutr 2010;91:184-90.

[6] Loos RJ. Genetic determinants of common obesity and their value in prediction. Best Pract Res 2012;26:211-26.

Table 5

Multiple regression between body weight at baseline and body weight changes with SNPs, dietary restraint and disinhibition.

\begin{tabular}{|c|c|c|c|c|}
\hline Response & Parameter & $\mathrm{B} \pm \mathrm{SE}$ & $\beta$ & P-value \\
\hline \multirow[t]{5}{*}{ Body weight (t0) } & Age & $0.01 \pm 0.10$ & 0.00 & 0.959 \\
\hline & Gender & $-13.69 \pm 2.17$ & -0.49 & 0.000 \\
\hline & FTO & $3.26 \pm 1.29$ & 0.18 & 0.012 \\
\hline & Dietary restraint (t0) & $0.11 \pm 0.24$ & 0.03 & 0.654 \\
\hline & Disinhibition (t0) & $-0.48 \pm 0.33$ & -0.11 & 0.156 \\
\hline \multirow[t]{6}{*}{ Short-term weight loss $(\mathrm{t} 2-0)$} & Age & $0.03 \pm 0.03$ & 0.06 & 0.410 \\
\hline & Gender & $2.70 \pm 0.78$ & 0.29 & 0.001 \\
\hline & PPARGC1A & $-1.15 \pm 0.42$ & -0.20 & 0.008 \\
\hline & Body weight (t0) & $-0.11 \pm 0.03$ & -0.33 & 0.000 \\
\hline & Dietary restraint $(\mathrm{t} 2-0)$ & $-0.06 \pm 0.06$ & -0.07 & 0.346 \\
\hline & Disinhibition $(\mathrm{t} 2-0)$ & $0.01 \pm 0.12$ & 0.01 & 0.912 \\
\hline \multirow[t]{6}{*}{ Long-term weight loss $(\mathrm{t} 5-0)$} & Age & $-0.05 \pm 0.03$ & -0.08 & 0.077 \\
\hline & Gender & $-1.94 \pm 0.61$ & -0.17 & 0.002 \\
\hline & $M C 4 R$ & $0.57 \pm 0.37$ & 0.07 & 0.123 \\
\hline & Weight loss $(\mathrm{t} 2-0)$ & $1.02 \pm 0.07$ & 0.82 & 0.000 \\
\hline & Dietary restraint $(\mathrm{t} 5-0)$ & $-0.23 \pm 0.07$ & -0.18 & 0.001 \\
\hline & Disinhibition $(\mathrm{t} 5-0)$ & $0.25 \pm 0.11$ & 0.12 & 0.024 \\
\hline
\end{tabular}

Response; dependent variable.

Parameter; independent variable.

$\mathrm{B}$; unstandardized regression coefficient.

$\beta$; standardized regression coefficient. 
[7] Speliotes EK, Willer CJ, Berndt SI, Monda KL, Thorleifsson G, Jackson AU, et al. Association analyses of 249,796 individuals reveal 18 new loci associated with body mass index. Nat Genet 2010;42:937-48.

[8] Wing RR, Hill JO. Successful weight loss maintenance. Annu Rev Nutr 2001;21:323-41.

[9] Wing RR, Phelan S. Long-term weight loss maintenance. Am J Clin Nutr 2005;82:222S-5S.

[10] Mariman E. Human biology of weight maintenance after weight loss. J Nutrigenet Nutrigenomics 2012;5:13-38.

[11] Bouchard C, Tremblay A, Despres JP, Theriault G, Nadeau A, Lupien PJ, et al. The response to exercise with constant energy intake in identical twins. Obes Res 1994;2:400-10.

[12] Hainer V, Stunkard AJ, Kunesova M, Parizkova J, Stich V, Allison DB. Intrapair resemblance in very low calorie diet-induced weight loss in female obese identical twins. Int J Obes Relat Metab Disord 2000;24:1051-7.

[13] Dempster P, Aitkens S. A new air displacement method for the determination of human body composition. Med Sci Sports Exerc 1995;27:1692-7.

[14] Westerterp KR, Wouters L, van Marken Lichtenbelt WD. The Maastricht protocol for the measurement of body composition and energy expenditure with labeled water. Obes Res 1995;3(Suppl. 1):49-57.

[15] Siri W. Body composition from fluid spaces and density: analysis of methods. In: Brozek J, Henschel A, editors. Techniques for measuring body composition. Washington DC: National Academy of Science; 1961. p. 223-44.

[16] Stunkard A, Messick S. The three-factor eating questionnaire to measure dietary restraint, disinhibition and hunger. J Psychosom Res 1985;29:71-83.

[17] Bryant EJ, King NA, Blundell JE. Disinhibition: its effects on appetite and weight regulation. Obes Rev 2008;9:409-19.

[18] den Hoed M, Ekelund U, Brage S, Grontved A, Zhao JH, Sharp SJ, et al. Genetic susceptibility to obesity and related traits in childhood and adolescence: influence of loci identified by genome-wide association studies. Diabetes 2010;59:2980-8.

[19] Peterson RE, Maes HH, Holmans P, Sanders AR, Levinson DF, Shi J, et al. Genetic risk sum score comprised of common polygenic variation is associated with body mass index. Hum Genet 2011;129:221-30.

[20] Franks PW, Jablonski KA, Delahanty LM, McAteer JB, Kahn SE, Knowler WC, et al. Assessing gene-treatment interactions at the FTO and INSIG2 loci on obesity-related traits in the Diabetes Prevention Program. Diabetologia 2008:51:2214-23.

[21] Grau K, Hansen T, Holst C, Astrup A, Saris WH, Arner P, et al. Macronutrient-specific effect of FTO rs9939609 in response to a 10-week randomized hypo-energetic diet among obese Europeans. Int J Obes 2009;33:1227-34 [(2005)].

[22] Lappalainen TJ, Tolppanen AM, Kolehmainen M, Schwab U, Lindstrom J, Tuomilehto $\mathrm{J}$, et al. The common variant in the FTO gene did not modify the effect of lifestyle changes on body weight: the Finnish Diabetes Prevention Study. Obesity (Silver Spring) 2009; 17:832-6 [Md].

[23] Goyenechea E, Crujeiras AB, Abete I, Parra D, Martinez JA. Enhanced short-term improvement of insulin response to a low-caloric diet in obese carriers the Gly482Ser variant of the PGC-1alpha gene. Diabetes Res Clin Pract 2008;82:190-6.

[24] Mirzaei K, Hossein-Nezhad A, Emamgholipour S, Ansar H, Khosrofar M, Tootee A et al. An exonic peroxisome proliferator-activated receptor-gamma coactivator-1 alpha variation may mediate the resting energy expenditure through a potential regulatory role on important gene expression in this pathway. J Nutrigenet Nutrigenomics 2012;5:59-71.
[25] Haupt A, Thamer C, Heni M, Tschritter O, Machann J, Schick F, et al. Impact of variation near MC4R on whole-body fat distribution, liver fat, and weight loss. Obesity (Silver Spring) 2009;17:1942-5 [Md].

[26] Kring SI, Holst C, Toubro S, Astrup A, Hansen T, Pedersen O, et al. Common variants near MC4R in relation to body fat, body fat distribution, metabolic traits and energy expenditure. Int J Obes 2010;34:182-9 [(2005)].

[27] Masuo K, Katsuya T, Kawaguchi H, Fu Y, Rakugi H, Ogihara T, et al. Rebound weight gain as associated with high plasma norepinephrine levels that are mediated through polymorphisms in the [beta]2-adrenoceptor. Am J Hypertens 2005;18:1508-16.

[28] Ruiz JR, Larrarte E, Margareto J, Ares R, Labayen I. Role of beta(2)-adrenergic receptor polymorphisms on body weight and body composition response to energy restriction in obese women: preliminary results. Obesity (Silver Spring) 2011;19:212-5 [Md].

[29] Goyenechea E, Dolores Parra M, Alfredo Martinez J. Weight regain after slimming induced by an energy-restricted diet depends on interleukin-6 and peroxisome-proliferator-activated-receptor-gamma2 gene polymorphisms. $\mathrm{Br}$ J Nutr 2006;96:965-72.

[30] Lindi VI, Uusitupa MI, Lindstrom J, Louheranta A, Eriksson JG, Valle TT, et al. Association of the Pro12Ala polymorphism in the PPAR-gamma2 gene with 3-year incidence of type 2 diabetes and body weight change in the Finnish Diabetes Prevention Study. Diabetes 2002;51:2581-6.

[31] Nicklas BJ, van Rossum EFC, Berman DM, Ryan AS, Dennis KE, Shuldiner AR. Genetic variation in the peroxisome proliferator, activated receptor- $\gamma 2$ gene (Pro12Ala) affects metabolic responses to weight loss and subsequent weight regain. Diabetes 2001;50:2172-6

[32] Rosmond R, Chagnon M, Bouchard C. The Pro12Ala PPARgamma2 gene missense mutation is associated with obesity and insulin resistance in Swedish middle-aged men. Diabetes Metab Res Rev 2003;19:159-63.

[33] Vogels N, Mariman ECM, Bouwman FG, Kester ADM, Diepvens K, WesterterpPlantenga MS. Relation of weight maintenance and dietary restraint to peroxisome proliferator-activated receptor \{gamma\}2, glucocorticoid receptor, and ciliary neurotrophic factor polymorphisms. Am J Clin Nutr 2005;82:740-6.

[34] Andreasen CH, Andersen G. Gene-environment interactions and obesity-further aspects of genomewide association studies. , 25Nutrition (Burbank, Los Angeles County, Calif); 2009 998-1003.

[35] Dykes J, Brunner EJ, Martikainen PT, Wardle J. Socioeconomic gradient in body size and obesity among women: the role of dietary restraint, disinhibition and hunger in the Whitehall II study. Int J Obes Relat Metab Disord 2004;28:262-8.

[36] Hays NP, Bathalon GP, McCrory MA, Roubenoff R, Lipman R, Roberts SB. Eating behavior correlates of adult weight gain and obesity in healthy women aged 55-65 y. Am J Clin Nutr 2002;75:476-83.

[37] Vogels N, Westerterp-Plantenga MS. Successful long-term weight maintenance: a 2year follow-up. Obesity (Silver Spring) 2007:15:1258-66 [Md].

[38] Williamson DA, Lawson OJ, Brooks ER, Wozniak PJ, Ryan DH, Bray GA, et al. Association of body mass with dietary restraint and disinhibition. Appetite 1995;25:31-41.

[39] Lejeune MP, Van Aggel-Leijssen DP, Van Baak MA, Westerterp-Plantenga MS. Effects of dietary restraint vs exercise during weight maintenance in obese men. Eur J Clin Nutr 2003;57:1338-44.

[40] Westerterp-Plantenga MS, Kempen KP, Saris WH. Determinants of weight maintenance in women after diet-induced weight reduction. Int J Obes Relat Metab Disord 1998;22:1-6. 